ウマの胎子性腺における間質細胞の形態計測

\author{
角田 修男・町田 登 ${ }^{1)}$ - 永田 俊一 ${ }^{2}$ 長嶺 夏子 ${ }^{1 ）}$ - 南保 泰雄 ${ }^{3)}$ \\ 及川 正明 ${ }^{3)} \cdot$ 谷山 弘行 ${ }^{4)} \cdot$ 渡辺 元 $^{1)} \cdot$ 田谷 一善 ${ }^{1)}$ \\ シャダイ スタリオン ステイション テ059-14 北海道勇払郡早来町源武 275 \\ 1) 東京農工大学農学部獣医学科 $\boldsymbol{T} 183$ 東京都府中市幸町 3-5-8 \\ 2) 競走馬理化学研究所 $\mathbf{T} 158$ 東京都世田谷区上用賀 4-37-6 \\ 3) 日本中央競馬会競走馬総合研究所 干154 東京都世田谷区弦巻5-27-7

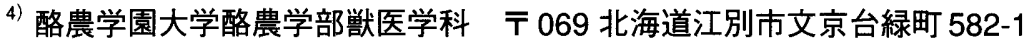

\begin{abstract}
要 約 妊娠後半期における母馬の血中インヒビン濃度の上昇に, 胎子性腺の間質細胞が関与している可能性を 検討する目的で, 胎齢 120 日〜 330 日のサラブレッド種 16 例の胎子性腺における間質細胞の量的変化について 経時的に調べた. 胎子性腺の間質細胞は胎跉 250 日前後をピークとして増殖・肥大し，それ以降は出生時まで急 速に退行した.このように間質細胞の量的推移が, 母馬の血中インヒビン濃度の変化と時期的に概ね一致してい たこと，ならびに免疫組織化学的に間質細胞にインヒビンの局在が認められたことから, 胎子性腺がインヒビン の分泌源である可能性が示唆された.

キーワード : Fetal horse, Gonad, Interstitial cell, Inhibin, Morphometry.
\end{abstract}

(Journal of Reproduction and Development, 42 : j91-j95, 1996)

胎生期におけるウマの性腺は, 体の大きさに比べて著 しく大きいことを特徴としている. ウマ胎子の性腺重 量は, 雌雄ともに胎齢 100 日あるいは 150 日以降急速に 堌加し，250日前後でピーク（両側の合計で50〜100 g) に達した後に減少に転じ，出生時には胎齢 180 日頃と同 程度の重さ（同 $10 \sim 20 \mathrm{~g}$ ）に至る $[1-4]$ 。このよう なウマ胎子における性腺の大きさの急激な増大と減少 は, 間質細胞 (interstitial cell) の増殖・肥大とその後に 生ずる変性・萎縮 (退行性事象) の結果であり [1-4], 性腺発育の引き金となるのが，妊娠 $80 \sim 100$ 日の母馬 の循環血液中に存在する高レベルの性腺刺激ホルモン (PMSG) であろうと考えられている $[3,5,6]$.

ウマ胎子性腺の間質細胞は形態的に黄体細胞によく 似ており，豊富な滑面小胞体とゴルジ装置を有するな

掲載採用：1996年 9 月 11 日
ど，ステロイド分泌細胞の特徵を備えている $[3-6]$. また，妊娠後半期に胎子性腺を摘出した実験の結果か ら，胎子の性腺は妊娠馬におけるエストロゲンの産生 や妊娠の維持に重要な役割を演じている可能性が推察 されている $[7,8]$ 。このように，ウマ胎子性腺の間質 細胞は他の動物の胎子とは明らかに異なった機能を有 している可能性があるが，その急速な発育および退行 を調節しているメカニズム等々についてはいまだ不明 な点が多い. 最近, 南保らは妊娠後半期の母馬血中に インヒビン $\alpha$ 鎖関連物質が一過性に出現することを明 らかにした [9].また，胎子性腺の抽出物中にはイン ヒビン $\alpha$ 鎖関連物質が高濃度に含有されていること, ならびに免疫組織化学的に胎子性腺の間質細胞にイン ヒビン $\alpha$ 鎖関連物質の局在を認めたことから，胎子性 腺の間質細胞がその分泌源となっている可能性を示唆 した。 そこで本研究では，妊娠後半期における母体血 
中のインヒビン $\alpha$ 鎖関連物質の動態と胎子性腺の形態学 的変化とを比較する目的で, ウマの胎子性腺における間 質細胞の量的な動きを形態計測により追究した。

\section{材料と方法}

本検索には，胎齢 120 日から 330 日までのサラブレッ ド種の正常胎子 7 例および流・死産胎子 9 例から得た左 右いずれか一方の性腺を用いた。流・死産胎子の内訳は 臍帯捻転 3 例, 双胎流産 2 例，難産による擎死 2 例，な らびに原因不明 2 例である.

組織切片の作製にあたっては，10％中性緩衝ホルマ リン溶液あるいはメタカルン溶液内で浸漬固定された性 腺から厚さ $3 \mathrm{~mm}$ の組織片を切り出し, 定法に従って 5 $\mu \mathrm{m}$ のパラフィン切片とし, ヘマトキシリン・エオジン 染色を行なった. また, 胎齢 223 日の雌 1 例の性腺組織 薄切片（メタカルン固定, 厚さ $8 \mu \mathrm{m}$ ) について, ブタ インヒビン $\alpha$ 鎖 $(1-30)$ 合成ペプチドに対するウサ ギ・ポリクロナール抗体を用いて，その性腺内局在を免 疫組織化学的に検索した.

性腺組織に占める間質細胞の容積パーセント（volume fraction）の計測にあたっては，40倍の対物レンズと 2.5 倍の中間レンズを用いてカラーモニタ上に写し出された 組織像の上に $1 \mathrm{~cm}$ 角の格子 $(20 \times 15 \mathrm{~cm})$ を重ね合わ せ，ポイント・カウンティング法により異なった 5 視野 ( 1 視野： $4.32 \times 10^{4} \mu \mathrm{m}^{2}$ ) の平均值（土標準偏差）を求 めた，併せて，各々の視野の中に存在する間質細胞数を 数えてその平均值（土標準偏差）を求め, 単位面積あた りの間質細胞数とした.

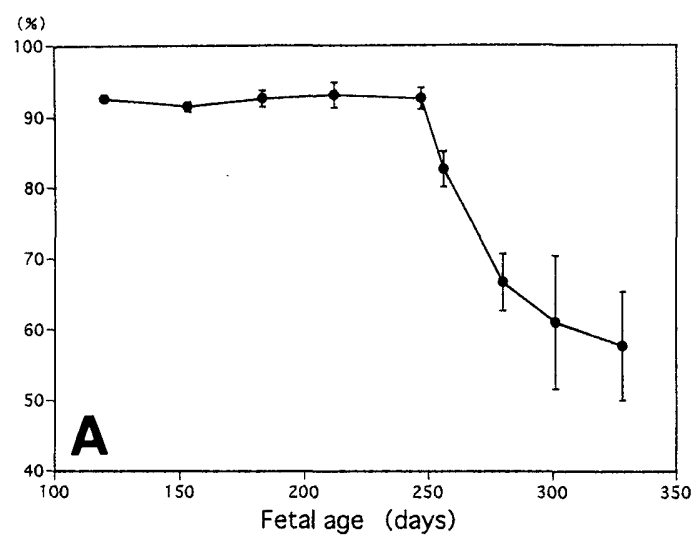

\section{結果}

\section{1. 性腺組織に占める間質細胞の容積パーセント（vol-} ume fraction)

間質細胞の容積パーセントは, 雌雄ともに同様な動き を示した（Fig. 1 A, B）. すなわち, 胎齢250日前後まで およそ90\%でほぼ一定していた間質細胞の容積分画は, その後, 急速かつ連続的に減少し, 出生時に最低值に至 った（雄： $57.7 \%$ ，䧳： $61.1 \%$ ）。また，間質細胞の大 きさは250日齢以前は各細胞間で概ね均一であったが, 250 日齢以降, 退行性変化 (変性・萎縮・消失) を示す間 質細胞が次第に増加し, 退行する細胞と残存する細胞と の大きさの差が顕著になるとともに, 各視野間での容積 パーセントのバラツキも大きくなった（Fig. $2 \mathrm{~A}, \mathrm{~B}, \mathrm{C}$ ).

\section{2. 単位面積あたりの間質細胞数}

単位面積あたりの間質細胞数は, 雌雄ともに間質細胞 が増殖・肥大の途上にある 250 日齢以前は減少する傾向 を示したが，それ以降は間質細胞の変性・萎縮と相まっ てやや増加する傾向を示した，また，間質細胞の退行性 変化の影響を受けて，250日齢以降は各視野間での間質 細胞数のバラッキがより大きくなった（Fig. $3 \mathrm{~A}, \mathrm{~B}$ ).

\section{3. インヒビンの免疫組織化学的検索}

インヒビン $\alpha$ 鎖 $(1-30)$ 合成ペプチドは，ほとん どすべての間質細胞の細胞質内に検出された（Fig. 4).

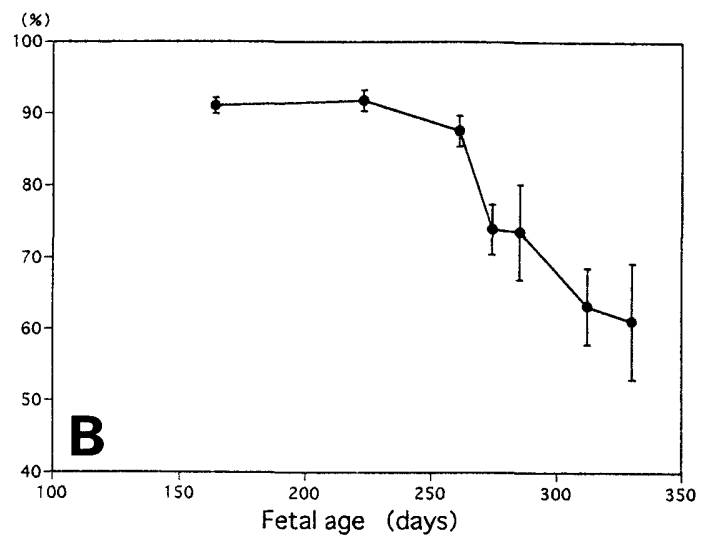

Fig. 1. Interstitial cell volume (\% of gonad tissue volume) in the male (A) and female (B) fetal gonad. 

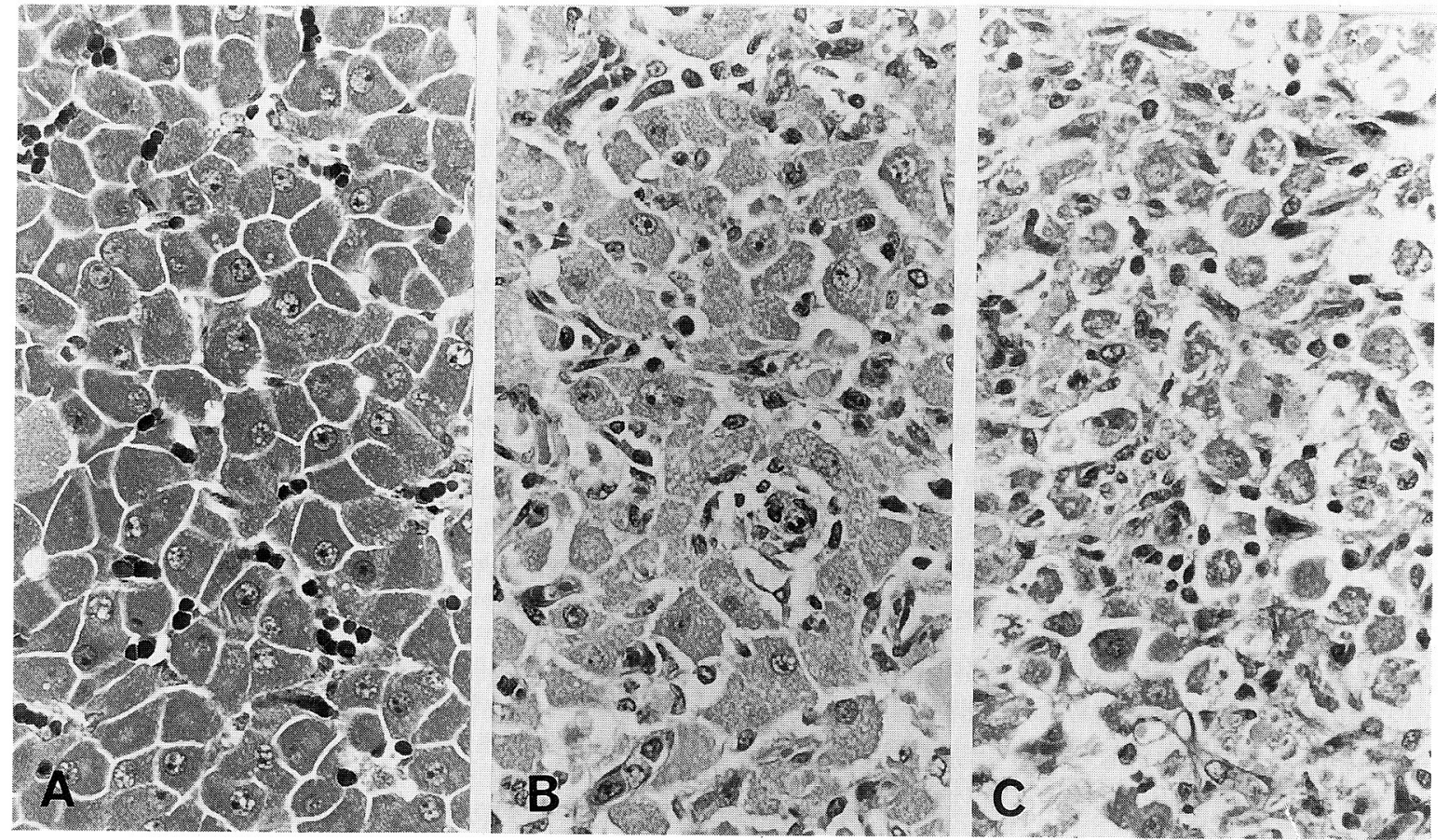

Fig. 2. Interstitial cells of the fetal gonads in 247-(A), 280-(B) and 328-(C) day-old male fetuses. H\&E $\times 405$.
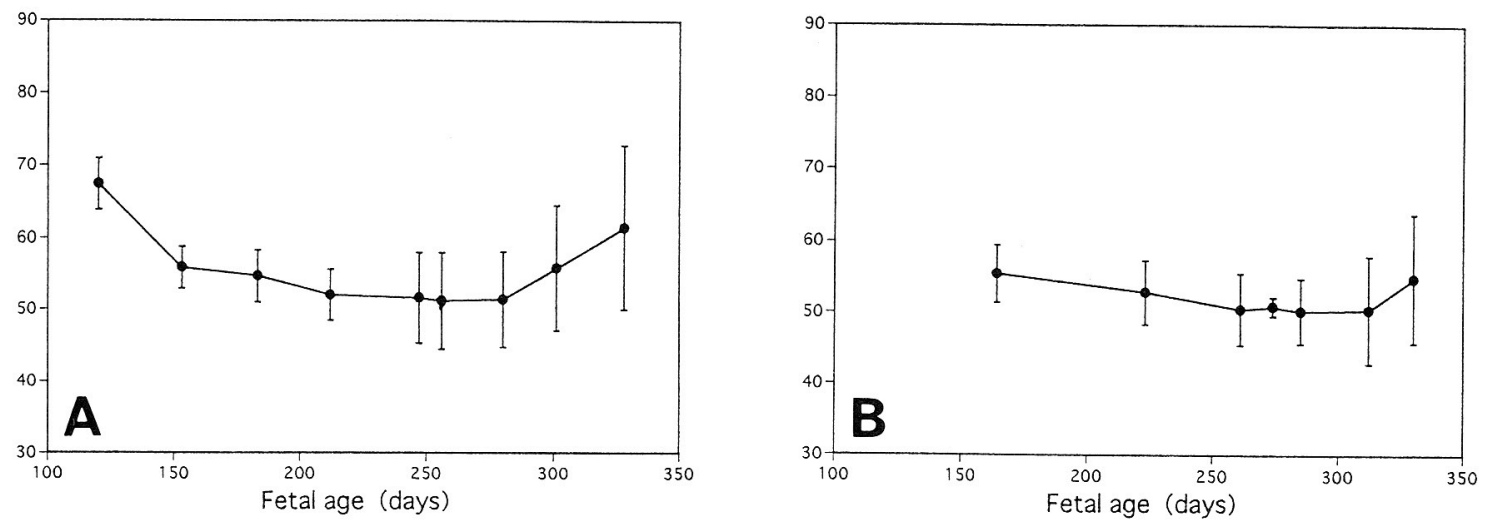

Fig. 3. Total number of interstitial cells $/ 4.32 \times 10^{4} \mu \mathrm{m}^{2}$ in the male (A) and female (B) fetal gonad.

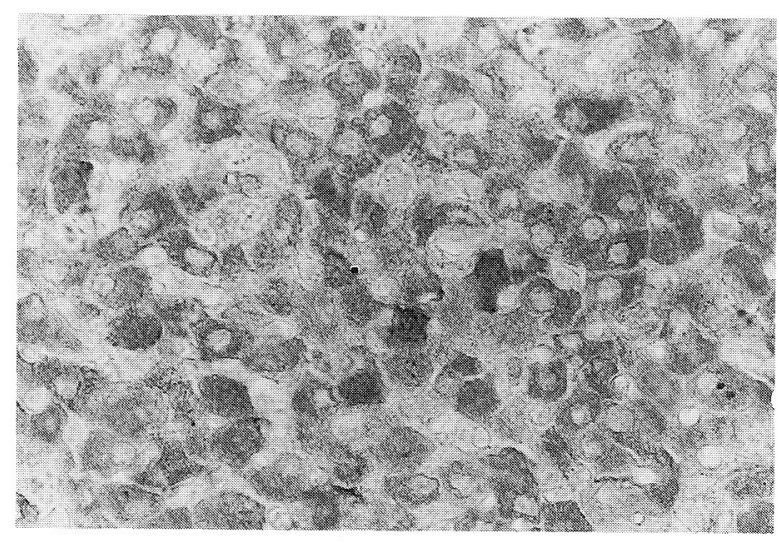

Fig. 4. Inhibin-specific antigen in interstitial cells of the female fetal gonad at 223 day of gestation. Immunoperoxidase staining $\times 300$. 


\section{考察}

南保らは，サラブレッド種雌馬について，妊娠約 140 日目から分婏までの母体の血中インヒビン濃度を測定し た結果, 妊娠 140～220日においては検出不能であった インヒビンが，220日頃から検出され始め, 280 日頃に ピークに達した後, 分婏 1 カ月前までに基底レベルにま で低下することを初めて明らかにした [9]. さらにこ のような妊娠後半期の母体血中に出現するインヒビンの 分泌源について検討した結果，1)胎盤抽出物にはインヒ ビンが検出されないこと，2)この時期の母体卵巣には大 型の卵胞は存在しないが，3)この時期にほぼ一致して重 量が著しく増加する胎子性腺の抽出物中には多量のイン ヒビンが検出されるとともに，4)胎子性腺の間質細胞内 にインヒビンの局在が認められることなどから，インヒ ビンの分泌源は胎子の性腺であろうと推察している。

今回実施したウマ胎子性腺における間質細胞の形態計 測の結果から, 間質細胞の形態ならびに数量的観点に立 った場合, ウマ胎子の性腺は雌雄とも250日齢前後をピ 一クとして発達し，それ以後，急速に退行してゆくもの と推察される。このような間質細胞の量的推移, とくに そのピーク時期は，胎子性腺の重量が胎齢 200～220日 をピークとするColeら［1］の報告よりもわずかに遅れ て出現しているが, 南保ら [9] の母体血中のインヒビ ン濃度の変化と時期的にほぼ一致している。胎子性腺の 間質細胞にインヒビンの局在が認められたことを考え併 せると，本検索結果は，妊娠後半期において母馬血中に 増加するインヒビンの分泌源は胎子性腺であろうとする 南保ら [9] の仮説をさらに裏付けるものである.

なお，胎子性腺から分泌されるインヒビンの生理学的 意義については，現時点で明らかではないが，既に指摘 されている妊娠馬におけるエストロゲンの産生や妊娠維 持などとの関連性も含めて今後, 検討をすすめるべき点 である。

\section{謝辞}

本研究に用いたブタインヒビン $\alpha$ 鎖 $(1-30)$ 抗体 の作製にあたり，抗原を御提供頂いたN.Ling 博士 (Neurocrine Biosciences Inc., La Jolla, CA, U.S.A) に感謝 する。

本研究は，日本中央競馬会委託研究の一部である.

\section{文献}

1. Cole HH, Hart GH, Lyons WR, Catchpole HR. The development and hormonal content of fetal horse gonads. Anat Rec 1933; 56: 275-293.

2. Sakai T. Studies on the development of the embryonic ovary in swine, cattle and horse. Jap J Vet Res 1955; 3: 183-194.

3. Hay MF, Allen WR. An ultrastructural and histochemical study of the interstitial cells in the gonads of the fetal horse. J Reprod Fert 1975; suppl 23: 557-561.

4. Ginther OJ. Reproductive Biology of the Mare: Basic and Applied Aspects, 2nd ed, Wisconsin: Equiservices; 1992; $397-400$.

5. Gonzalez-Angulo A, Hernandez-Jauregui P, Marquez-Monter H. Fine structure of gonads of the fetus of the horse (Equus caballus).

Am J Vet Res 1971; 32: 1665-1676.

6. Gonzalez-Angulo A, Hernandez-Jauregui P, Martinez-Zedilo G. Fine structure of the gonads of the horse and its functional implications. J Reprod Fert 1975; suppl 23: 563-567.

7. Raeside JI, Liptrap RM, Milne FJ. Relationship of fetal gonads to urinary estrogen excretion by the pregnant mare. Am J Vet Res 1973; 34: 843-845.

8. Pashen RL, Allen WR. The role of the fetal gonads and placenta in steroid production, maintenance of pregnancy and parturition in the mare. $J$ Reprod Fert 1979; suppl 27: 499-509.

9. Nambo $Y$, Nagata $S$, Oikawa M, Yoshihara T, Tsunoda N, Kohsaka T, Taniyama H, Watanabe G, Taya K. High concentrations of immunoreactive inhibin in the plasma of mares and fetal gonads during the second half of pregnancy. Reprod Fert Dev 1996; 8: 1137-1145. 


\title{
A Morphometric Study of Interstitial Cells in Equine Fetal Gonads
}

\author{
Nobuo Tsunoda, Noboru Machida ${ }^{1)}$, Shun-ichi Nagata ${ }^{2)}$, Natsuko Nagamine, ${ }^{1)}$ Yasuo Nambo ${ }^{3)}$, \\ Masaaki OIKAWA $^{3)}$, Hiroyuki TANIYAMA ${ }^{4)}$, Gen WATANABE ${ }^{1)}$ and Kazuyoshi TAYA ${ }^{1)}$ \\ Shadai Stallion Station, $275 \mathrm{Genbu}$, Hayakita-cho, Yufutsu-gun, Hokkaido 059-14 \\ ${ }^{1)}$ Department of Veterinary Medicine, Tokyo University of Agriculture and Technology, 3-5-8 Saiwai- \\ cho, Fuchu, Tokyo 183 \\ ${ }^{2)}$ Laboratory of Racing Chemistry, 4-37-6 Kamiyoga, Setagaya-ku, Tokyo 158 \\ 3) Japan Racing Association, Equine Research Institute, 5-27-7 Tsurumaki, Setagaya-ku, Tokyo 154 \\ ${ }^{4)}$ Department of Veterinary Medicine, Rakuno Gakuen University, 582-1 Midori-cho, Bunkyoudai, \\ Ebetsu-shi, Hokkaido 069.
}

Summary. A morphometric study of gonadal interstitial cells in 16 equine fetuses, ranging in age from 120 to 330 days of fetal age, was done to assess the possible relationship of fetal gonads to high plasma concentrations of immunoreactive inhibin in pregnant mares during the second half of pregnancy with its peak at about 280 days of gestation, which has been reported recently. Interstitial cells of fetal gonads underwent progressive hypertrophy to reach a maximum size around 250 days of gestation, and subsequent degenerative changes in these cells resulted in a rapid decrease in the volume density and size of the interstitial cells. Thus, the morphometric change in the interstitial cells was almost synchronous with high concentrations of immunoreactive inhibin in the plasma of pregnant mares. This observation, taken in conjunction with the fact that inhibin $\alpha$-chain (1-30) was detected immunohistochemically in the cytoplasm of the interstitial cells, appears to provide morphometric evidence that the interstitial cells in fetal gonads are closely related to inhibin production. 